\title{
Impact of Private Investment, Economic Growth and Financial Development on Environmental Degradation: Evidence from Pakistan
}

\author{
Shabana Parveen ${ }^{a}$, Bibi Aisha Sadiqa ${ }^{\text {b }}$, Sher Ali ${ }^{\text {c }}$, Farrah Yasmin ${ }^{\text {d }}$ \\ a Assistant Professor, Department of Economics, Hazara University Mansehra, Pakistan \\ Email: shabana_economist@yahoo.com \\ ${ }^{\mathrm{b}}$ Assistant Professor, Department of Economics, Hazara University Mansehra, Pakistan \\ Email: agrieco24@yahoo.com \\ ${ }^{c}$ Assistant Professor, Department of Economics, Islamia College Peshawar, Pakistan \\ Email: drali@icp.edu.pk \\ d Assistant Professor of Economics, Govt. Emerson College Multan, Pakistan \\ Email: farraheconomist@gmail.com
}

\begin{tabular}{|c|c|}
\hline ARTICLE DETAILS & ABSTRACT \\
\hline History: & \multirow{9}{*}{$\begin{array}{l}\text { Private investment plays an important role in the process of economic } \\
\text { growth and also impact natural environment of a country. The main } \\
\text { purpose of the present study is to empirically analyze the impact of } \\
\text { private investment and other macro economic variables on } \\
\text { environmental degradation of Pakistan. For the purpose, time series data } \\
\text { is collected for the years } 1975 \text { to 2017. The study used Linear regression } \\
\text { model for analyzing the impact of private investment, energy } \\
\text { consumption, financial development and economic growth on } \\
\text { environmental degradation. Augmented Dickey Fuller (ADF) test and } \\
\text { Phillips Perron (PP) test is used for identifying the unit root of the } \\
\text { variables; first with an intercept then, with an intercept and a linear } \\
\text { deterministic trend. Akaike Information Criterion (AIC) is used for } \\
\text { selection of optimum lag whereas Johansen cointegration test is adopted } \\
\text { for analyzing long run association in the variables. The results of linear } \\
\text { regression model show that energy consumption and economic growth } \\
\text { have a positive and statistically significant impact on CO2 emissions } \\
\text { whereas the impact of private investment on CO2 emissions is negative. } \\
\text { It means that in Pakistan, private investment is environment friendly. } \\
\text { Based on study results, it is recommended that when formulating } \\
\text { policies for economic growth and development, motivation should be } \\
\text { given to private inverters in order to increase private investment. }\end{array}$} \\
\hline Accepted 25 Feb 2021 & \\
\hline Available Online March 2021 & \\
\hline Keyw & \\
\hline & \\
\hline & \\
\hline JEL C & \\
\hline$R_{42}$, & \\
\hline DOI: $10.47067 /$ reads.v7i1.313 & \\
\hline
\end{tabular}

(C) 2021 The authors. Published by SPCRD Global Publishing. This is an open access article under the Creative Commons Attribution-

NonCommercial 4.0

Corresponding author’s email address: shabana_economist@yahoo.com

\section{Introduction}

Economic health of a country is reflected by its economic growth which is indicated by an 
increase in Gross Domestic Product (GDP). GDP is defined as the total market value of all final goods and services produced by an economy during one financial year. A general agreement in all countries is that, economic growth and investment are closely inter connected as investment/capital formation leads to GDP growth. Economists such as New classical and Marxist suggested capital formation for GDP growth and consider investment as an engine for economic growth of a country. Due to investment, an increase occurs in capital goods that in turn leads to the production of other goods and boost the growth and income (Anwar and Sampath,1999). All growth models consider capital as one of the two central components for determining economic growth. Increase in capital is must for increasing production as GDP is higher in those countries that have high investment to GDP ratio. Likewise, endogenous growth theory suggests that investment is a key component for long run economic growth. Similarly, empirical studies confirmed the role of investment for better economic performance as investment promotes employment opportunities, improve technical progress, brings new techniques of production that helps in economic growth. Investment maintains long run economic growth through capital accumulation as suggested by Tadele (2014).

Investment in any country consists of public and private investment. Public investment means investment done by government on services like education and health etc. Private investment is investment done by private investers for the sake of profit. To answer whether public or private investment is better for robust economic growth, empirical studies presented that private sector investment is better as it increases economic growth by bringing more innovation, job creation, high revenue and improve the performance of human resources. Majid and Khan (2008) concluded that economic growth is higher in the countries that have more private investment. Tadele (2014) added that private investment brings robust economic growth due to less corruption and other such factors. Similarly, Muhammad and Shaheen (2016) proved that the effect of private investment is stronger on economic growth as private investment is more transparent and efficient as compare to public investment. So it plays a crucial role for uplifting economic growth. Attention has been given to increase private investment especially in developing economies in order to reduce unemployment and increase economic growth.

Private investment accelerates economic growth but economic growth is the cause of environmental problem as increase in production contributes to more pollution. Some of the studies considered it as a greatest challenge for all economies (Cederbary and Snobohn, 2016). Yousaf et al. (2016) showed that in Pakistan, GDP per capita, energy consumption, and Foreign Direct Investment (FDI) are positive determinants of environmental degradation. The study suggests that attention should be given to reduce Carbon Dioxide $\left(\mathrm{CO}_{2}\right)$ emissions with improvement in GDP and FDI. As $\mathrm{CO}_{2}$ emissions contributes about 6o\% of global warming (Sinha and Bhatt,2017). As Pakistan is a victim of global warming and environmental degradation so attention is needed to look at the impact of economic growth and private investment on environmental quality. Although in Pakistan, a lot of research work has been done on many other determinants of $\mathrm{CO}_{2}$ emissions such as GDP growth, energy use, urbanization, industrialization, trade openness as well as FDI, but it is dicorvered that private investment is a missing variable. The main purpose of the present study is trying to fill this research gap. This research work is a good contribution to the literature in general and in case of Pakistan in particular for analyzing the impact of private investment on degradation of environment in Pakistan.

The rest of the study is organized as follows. Section 2 represents the previous literature. Section 3 comprises the data and methodology. Section 4 is about the results and in section 5 , the research 


\section{Review of Economics and Development Studies, Vol. 7 (1) 2021, 13-24}

work is concluded along with some policy implications.

\section{Literature Review}

From the famous study of Grossman and Krueger (1991), the environmental Kuznets Curve (EKC) hypothesis has been empirically analyzed by researchers in different countries, by employing various indicators of environmental quality. Results provided by different researchers are not the same. Some studies Grossman and Krueger (1991) and Selden and Song (1994) support EKC hypothesis whereas some like, Saboori et al. (2012) contradict it. The EKC presents that degradation of environment first rises with the increasing level of income, then stabilize but after a turning point, it starts declining.

Rich literature is available that empirically worked on the association of financial development and emissions of $\mathrm{CO}_{2}$ on the basis of EKC hypothesis and presented mixed results. Studies like Sadosky (2011),Shahban and Lean (2012), Islam et al. (2013) and Tang and Tan (2014) presented a positive association of financial development and energy usage and emissions of $\mathrm{CO}_{2}$ whereas other studies like Jalil and Feridun ( 2011), and Shahbaz et al. (2013) confirmed negative association of financial development, energy usage and emissions of $\mathrm{CO}_{2}$. Likewise, other researchers reported that financial development effects $\mathrm{CO}_{2}$ emissions in many ways like, Zhang (2011) argued that financial intermediaries help in increasing loan availabilities to consumers that contribute to increase demand for houses and home appliances that is automobiles, refrigerators, air conditioners. All the things make life comfortable but also increase $\mathrm{CO}_{2}$ emissions. Sehrawat et al. (2015) provided that investment is the second reason of positive contribution of financial development on $\mathrm{CO}_{2}$ emissions. When more credit facility is provided to people by financial intermediaries, they invest money in new projects and business and directly contributes to $\mathrm{CO}_{2}$ emissions. Third, Tamazian and Rao (2010) presented that financial development has important role in increasing Foreign Direct Investment (FDI) inflows, accelerates economic growth as well as $\mathrm{CO}_{2}$ emissions. Fourth, Tamazian et al. (2009), and Kivyiro and Arminen (2014) showed that industrialization as well as economic growth accelerates due to financial development which contributes to pollution. In most of the empirical studies, researchers modeled the relationship of $\mathrm{CO}_{2}$ emissions and financial development by EKC and found a unidirectional relationship between the two, based on GDP growth and energy use ( Albiman et al., 2015). In addition, Tamazian and Rao (2010) in twenty four transition countries, Sadorsky (2011) for nine Central and Eastern European countries; Al-Mulali et al. (2013) for Middle East and North America (MENA) countries, and Mohapatra and Giri (2015) for India, found a positive cointegration between financial development and $\mathrm{CO}_{2}$ emissions. On the other hand, Jalil and Feridun (2011) in China presented a negative association between the two.

The assocaition between GDP growth and emissions of $\mathrm{CO}_{2}$ has been analyzed by researchers like, Yang et al. (2007), Song et al. (2008), Dhakal (2009), Jalil and Muhammad (2009), Fodha and Zaghdoud (2010), Wolde (2015). All the studies accepted the EKC hypothesis meaning that environmental degradation reduces due to economic growth, in long run. On the contrary, Akbostanci et al. (2009) not accepted the presence of EKC hypothesis between emissions of $\mathrm{CO}_{2}$ and income for Turkey. Researchers also found mixed result for the association of energy use and $\mathrm{CO}_{2}$ emissions. Studies such as, Hummami and Saidi (2015), Jamel and Derbeli (2016), Siddique et al. (2016) and, Pata (2017) presented a positive cointegration between energy use and $\mathrm{CO}_{2}$ emissions i.e. negative impact on environment. On the other hand, Zue et al. (2011) and Gokmenoglu and Sadeghieh (2019) suggest negative impact of energy consumption on emissions of $\mathrm{CO}_{2}$ i.e. positive impact of environment. 
Similarly, literature regarding energy consumption, GDP growth and their impact on emissions of $\mathrm{CO}_{2}$ provides mixed results. Studies such as Smyth and Lean (2010), Munir and Khan (2010), Borhan et al. (2012) and Kizilkaya (2017) presented a positive impact of GDP growth and energy use on $\mathrm{CO}_{2}$ emissions. Likewise, Ali et al. (2016) studied the impact of energy usage and GDP growth for Nigeria and presented a significant positive impact of both the variables on emissions of $\mathrm{CO}_{2}$. On the contrary, Thao and Chon (2015) found a negative impact of GDP growth and energy use on $\mathrm{CO}_{2}$ emissions. Azam et al. (2016) conducted a study for the association between energy consumption, trade and emissions of $\mathrm{CO}_{2}$. The study found a significant cointegration among the variables for USA, Japan, China and India. Similarly, Poumanyvong and Kaneko (2010) also confirmed a statistically significant cointegration between energy consumption and emissions of $\mathrm{CO}_{2}$ for USA, China, India and Japan.

Moreover, studies are conducted to analyze empirically the effect of many other macro economic variables like FDI, trade openness, industrialization, urbanization with association of energy consumption on emissions of $\mathrm{CO}_{2}$ yet, it is discovered that private investment is a missing variable in the literature. To mention just few studies like, Talukdar and Meisner (2001) for developing countries, Fu et al.(2014) for China and Hassan (2018) for Malaysia, studied the impact of private investment on environmental degradation. Talukdar and Meisner (2001) found that increase in private investment reduces environmental degradation in developing economies however, the impact of financial development and GDP growth was found insignificant in case of Malaysia.

The summary of the literature regarding the association between $\mathrm{CO}_{2}$ emissions with the macroeconomic variables (financial development, economc growth, energy consumption, private investment is presented below in Table 1.

\section{Table-1: Summary of Earlier Studies}

\begin{tabular}{|c|c|c|c|c|}
\hline Authors & $\begin{array}{l}\text { Sample and } \\
\text { time period }\end{array}$ & Variables & Methodology & Results \\
\hline $\begin{array}{l}\text { Talukdar } \\
\text { and Meisner } \\
\text { (2001) }\end{array}$ & $\begin{array}{l}44 \text { developing } \\
\text { countries }(1987- \\
1995)\end{array}$ & $\begin{array}{l}\text { Private } \\
\text { investment, } \\
\text { energy } \\
\text { consumption, } \\
\mathrm{CO}_{2} \text { emissioons }\end{array}$ & $\begin{array}{l}\text { Random-effects } \\
\text { model }\end{array}$ & $\begin{array}{l}\text { Increase in private } \\
\text { investment in developing } \\
\text { economies reduces } \mathrm{CO}_{2} \\
\text { emissions. }\end{array}$ \\
\hline $\begin{array}{l}\text { Tamazian et } \\
\text { al. (2010) }\end{array}$ & $\begin{array}{l}24 \quad \text { transition } \\
\text { economies } \\
(1993-2004)\end{array}$ & $\begin{array}{l}\text { Financial } \\
\text { development, } \\
\text { economic } \\
\text { development, } \\
\mathrm{CO}_{2} \text { emissions }\end{array}$ & $\begin{array}{l}\text { Beneralized } \\
\text { method of } \\
\text { movement(GMM } \\
\text { approach) }\end{array}$ & $\begin{array}{l}\text { Financial development and } \\
\text { economic development } \\
\text { increases } \mathrm{CO}_{2} \text { emissions/ } \\
\text { negative impact on } \\
\text { environmental quality. }\end{array}$ \\
\hline $\begin{array}{l}\text { Poumanyvon } \\
\text { g and } \\
\text { Kaneko }\end{array}$ & $\begin{array}{l}\text { China, USA, } \\
\text { India, } \\
\text { Japan(1971-2013) }\end{array}$ & $\begin{array}{l}\text { Energy } \\
\text { consumption, } \\
\text { trade, } \quad \mathrm{CO}_{2}\end{array}$ & $\begin{array}{l}\text { Panel-fully } \\
\text { modified } \\
\text { ordinary }\end{array}$ & $\begin{array}{l}\text { All the variables are } \\
\text { significantly associated. }\end{array}$ \\
\hline
\end{tabular}


Review of Economics and Development Studies, Vol. 7 (1) 2021, 13-24

\begin{tabular}{|c|c|c|c|c|}
\hline (2010) & & emissions & $\begin{array}{l}\text { squares (FMOLS) } \\
\text { method }\end{array}$ & \\
\hline $\begin{array}{l}\text { Fodha and } \\
\text { Zaghdoud } \\
\text { (2010) }\end{array}$ & $\begin{array}{l}\text { Tunisia(1961- } \\
\text { 2004) }\end{array}$ & $\begin{array}{l}\text { GDP per capita, } \\
\text { Sulfur dioxide } \\
\left(\mathrm{SO}_{2}\right), \quad \text { Carbon } \\
\text { dioxide } \\
\mathrm{CO}_{2} \\
\text { emissions. }\end{array}$ & $\begin{array}{l}\text { Cointegration } \\
\text { test }\end{array}$ & $\begin{array}{l}\text { Long run cointegration was } \\
\text { presented between per } \\
\text { capita GDP with emissions } \\
\text { of both both } \mathrm{CO}_{2} \text { and } \mathrm{SO}_{2} \text {. } \\
\text { Inverted } \mathrm{U} \text { shaped } \\
\text { relationship had identified } \\
\text { between per capita GDP } \\
\text { and emissions of } \mathrm{SO}_{2} \text {. }\end{array}$ \\
\hline $\begin{array}{l}\text { Hye et al } \\
(2013)\end{array}$ & $\begin{array}{l}\text { Indonesia(1975Q1 } \\
\text { - 2011Q4) }\end{array}$ & $\begin{array}{l}\text { Financial } \\
\text { development, } \\
\text { energy use, GDP } \\
\text { growth, }\end{array}$ & $\begin{array}{l}\text { Autoregressive } \\
\text { distributed lag } \\
\text { model(ARDL) } \\
\text { bound test }\end{array}$ & $\begin{array}{l}\text { Financial Development } \\
\text { contribution is inverse on } \\
\mathrm{CO}_{2} \text { emissions. }\end{array}$ \\
\hline $\begin{array}{l}\text { Sehrawat(20 } \\
\text { 15) }\end{array}$ & India (1971-2011) & $\begin{array}{l}\text { Emissions of } \\
\mathrm{CO}_{2}, \text { Financial } \\
\text { development, } \\
\text { GDP, and energy } \\
\text { consumption. }\end{array}$ & $\begin{array}{l}\text { ARDL and error } \\
\text { correction model } \\
(\mathrm{ECM})\end{array}$ & $\begin{array}{l}\text { Positive contribution of the } \\
\text { variables towards the } \\
\text { emissions of } \mathrm{CO}_{2} \text { in India. }\end{array}$ \\
\hline $\begin{array}{l}\text { Siddique et } \\
\text { al (2016) }\end{array}$ & $\begin{array}{l}\text { South Asia (1983- } \\
\text { 2013) }\end{array}$ & $\begin{array}{l}\text { Energy } \\
\text { consumption, } \\
\mathrm{GDP}, \mathrm{CO}_{2} \\
\text { emissions }\end{array}$ & $\begin{array}{l}\text { Panel } \\
\text { cointegration }\end{array}$ & $\begin{array}{l}\text { Positive contribution of the } \\
\text { variables towards the } \\
\text { emissions of } \mathrm{CO}_{2} \text {. }\end{array}$ \\
\hline $\begin{array}{l}\text { Ali et } \\
\text { al.(2016) }\end{array}$ & $\begin{array}{l}\text { Nigeria } \\
\text { 2011) }\end{array}$ & $\begin{array}{l}\text { GDP, } \mathrm{CO}_{2} \\
\text { emissions, trade } \\
\text { openness. }\end{array}$ & ARDL & $\begin{array}{l}\text { Positive contribution of the } \\
\text { variables towards the } \\
\text { emissions of } \mathrm{CO}_{2} \text { both in } \\
\text { short and long period. }\end{array}$ \\
\hline $\begin{array}{l}\text { Pata UK } \\
(2017)\end{array}$ & $\begin{array}{l}\text { Turkey } \\
\text { 2013) }\end{array}$ & $\begin{array}{l}\text { Per capita GDP, } \\
\text { energy } \\
\text { emissions }\end{array}$ & ARDL & $\begin{array}{l}\text { Positive contribution of the } \\
\text { variables towards the } \\
\text { emissions of } \mathrm{CO}_{2} \text { both in }\end{array}$ \\
\hline
\end{tabular}




\begin{tabular}{|c|c|c|c|c|}
\hline & & $\begin{array}{l}\mathrm{CO}_{2}, \quad \text { and } \\
\text { financial } \\
\text { development }\end{array}$ & & short and long term. \\
\hline $\begin{array}{l}\text { Hassan } \\
(2018)\end{array}$ & $\begin{array}{l}\text { Malaysia(1976- } \\
\text { 2013) }\end{array}$ & $\begin{array}{l}\mathrm{CO}_{2} \text {, emissions, } \\
\text { Private } \\
\text { Investment, } \\
\text { economic } \\
\text { growth, } \\
\text { financial } \\
\text { development, } \\
\text { energy use. }\end{array}$ & ARDL, ECM & $\begin{array}{l}\text { Private investment, energy } \\
\text { consumption shows } \\
\text { positive contribution on } \\
\text { emissions of } \mathrm{CO}_{2} \text {. } \\
\text { Financial development, } \\
\text { GDP growth shows } \\
\text { negative impact on } \mathrm{CO}_{2} \\
\text { emissions. }\end{array}$ \\
\hline
\end{tabular}

\section{Data and Empirical Method}

\subsection{Data Source and Variables Explanation}

The present study used time series data for the span of 1975 to 2017. The variables included in the study are $\mathrm{CO}_{2}$ emissions (metric tons per capita) which is used to represent environmental degradation, real private investment (used as a \% of real GDP), economic growth (real GDP growth rate), real financial development (Real commercial bank credit provided to private sector, \% of real GDP), energy consumption (kg of oil equivalent per capita. For all these variables, data is derived from World Bank Development Indicators (WDI).

\subsection{Model Specifications}

Researchers used different methods for analyzing the association between carbon dioxide $\left(\mathrm{CO}_{2}\right)$ emissions with other variables including energy consumption and GDP growth. The analytical techniques used by Azam et al. (2019) in his recent study are adopted for this study. First the Augmented Dickey and Fuller (1979) and Phillips and Perron (1988) tests have been adopted for cheking the stationarity of the data. Once it is confirmed that the variables are stationary at the same level, then Johansen's (1991, 1995) cointegration test is undertaken to analyze long-term cointegration among the variables. Linear Regression model is adopted for the evaluation of the coefficients.

The approach used by Jayanthakumaran et al. (2012) and Halicioglu (2009) is adopted for this research work to identify the association between $\mathrm{CO}_{2}$ emissions, private investment and other macroeconomic variables. The model used is as follows.

$$
C O_{2}=W_{0}+W_{1} P R I+W_{2} E G+W_{3} F D+W_{4} K T+\varepsilon_{1}
$$

Where $\mathrm{CO}_{2}$ is used for Carbon Dioxide Emissions (Metric tons per capita), PRI represents private investment, EG stands for economic growth (Real GDP annual growth in percentage), FD stands for financial development, KT represents energy consumption (Energy use, Kg of oil equivalent per capita) 
and $\varepsilon_{1}$ represents error term.

The expection for the direction of the slope coefficients is

$\mathrm{w}_{1}>_{0} ; \mathrm{w}_{2}>0 ; \mathrm{w}_{3}>0 ; \mathrm{w}_{4}>\mathrm{O}$

\section{Empirical Results}

\subsection{Result of ADF and PP Unit root tests}

For identifying stationarity in the data, Augmented Dickey-Fuller (ADF) (1979) as well as Phillips and Perron (1988) tests are used. Augmented Dickey-Fuller test in mathetical form can be presented as

$$
\Delta z_{t}=\sigma z_{t-1}+\dot{x} \delta+\epsilon_{t}
$$

where $\sigma=\rho-1-1 \leq \rho \leq 1$ and the model is hypothesized as:

$$
\begin{aligned}
& H_{0}: \sigma=0 \text { or } \rho=1 \\
& H_{1}: \sigma<0 \text { or }-1 \leq \rho \leq 0
\end{aligned}
$$

The t-ratio of the $\sigma$-coefficient of ADF test, when test statistic distribution is affected by serial correlation, is adjusted by Phillips-Perron (PP) test as follows:

$$
t_{\sigma}^{\prime}=t_{\sigma}\left(\frac{\gamma_{0}}{f_{0}}\right)^{1 / 2}-\frac{T\left(f_{0}-\gamma_{0}\right)(s e(\widehat{\sigma}))}{2 f_{0}^{\frac{1}{2}} s}
$$

Where $f_{\mathrm{o}}$ is the zero occurrence of residual and $\gamma_{\mathrm{o}}$ is the evaluation of error variance. The results of ADF and PP tests are presented in Table 2. It shows all the variables; economic growth, private investment, financial development, energy use and carbon dioxide emissions are non stationary at level at both trend, and with a trend and intercept. The variables are converted into stationary by taking first difference in ADF as well as PP test.

Table 2 Unit root test results

\begin{tabular}{|l|l|l|l|l|}
\hline \multirow{2}{*}{ Variables } & \multicolumn{2}{c|}{ ADF Test Result } & \multicolumn{2}{c|}{ PP-Test Result } \\
\cline { 2 - 5 } & Intercept & \multicolumn{1}{c|}{$\begin{array}{c}\text { Intercept } \\
\text { and Trend }\end{array}$} & \multicolumn{1}{c|}{ Intercept } & \multicolumn{1}{c|}{$\begin{array}{c}\text { Intercept } \\
\text { and Trend }\end{array}$} \\
\hline \multirow{2}{*}{ Real GDP } & -2.265 & -0.046 & -1.593 & 1.223 \\
\hline \multirow{2}{*}{ Real Private Investment (PRI) } & $-4.011^{*}$ & $-4.351^{*}$ & $-4.011^{*}$ & $-3.852^{*}$ \\
\hline \multirow{2}{*}{ Financial Development (FD) } & -0.470 & -1.341 & -0.501 & -1.341 \\
\cline { 2 - 5 } & $-6.258^{*}$ & $-6.449^{*}$ & $-6.258^{*}$ & $-6.459^{*}$ \\
\hline \multirow{2}{*}{ Energy Consumption (KT) } & -0.069 & -0.382 & 0.980 & 0.674 \\
\cline { 2 - 5 } & $-4.926^{*}$ & $-5.311^{*}$ & $-4.926^{*}$ & $-4.907^{*}$ \\
\hline \multirow{2}{*}{$\begin{array}{l}\text { Environmental Degradation }\left(\mathrm{CO}_{2}\right. \\
\text { emissions) }\end{array}$} & -2.056 & 0.152 & -1.952 & 0.151 \\
\cline { 2 - 5 } & $-5.404^{*}$ & $-6.332^{*}$ & $-5.471^{*}$ & $-6.349^{*}$ \\
\cline { 2 - 5 } & -2.235 & -2.149 & -4.043 & -1.741 \\
\hline \multirow{2}{*}{$*$ - } & $-7.727^{*}$ & $-8.260^{*}$ & $-7.627^{*}$ & $-17.126^{*}$ \\
\hline
\end{tabular}

*Significant at 5\% significance level 


\subsection{Cointegration Test Results}

Johansen (1988) suggested likelihood ratio tests to identify the presence of a long-term association among the variables. The tests can be presented in two different equations given below:

$$
\begin{aligned}
J_{\max } & =-T \ln \left(1-\widehat{\lambda_{r+1}}\right) \\
J_{\text {trace }} & =-T \sum_{i=r+1}^{n} \ln \left(1-\widehat{\lambda}_{l}\right)
\end{aligned}
$$

Where $\lambda^{\wedge} \mathrm{i}$ is the $\mathrm{i}^{\text {th }}$ largest known association. The $T$ presents the size of the sample in the above two equations. Table 3 represents the results of cointegration test. It indicates, for all five variables, the null hypothesis of no cointegration is not accepted meaning that longrun cointegration is confirmed in all variables.

Table 3 Cointegration test results

\begin{tabular}{|l|l|l|l|}
\hline \multirow{2}{*}{ N. Hypothesis } & \multicolumn{1}{|c|}{ A. Hypothesis } & \multicolumn{2}{c|}{ Trace Test Statistics } \\
\cline { 3 - 4 } & & \multicolumn{1}{c|}{ Statistics } & \multicolumn{1}{c|}{ Critical Value } \\
\hline $\mathrm{r}=\mathrm{o}$ & $\mathrm{r}=1$ & $106.35^{*}$ & 69.82 \\
\hline $\mathrm{r} \leq 1$ & $\mathrm{r}=2$ & $71.51^{*}$ & 47.86 \\
\hline $\mathrm{r} \leq 2$ & $\mathrm{r}=3$ & $40.65^{*}$ & 29.80 \\
\hline $\mathrm{r} \leq 3$ & $\mathrm{r}=4$ & $23.10^{*}$ & 15.49 \\
\hline $\mathrm{r} \leq 4$ & $\mathrm{r}=5$ & $6.48^{*}$ & 3.84 \\
\hline
\end{tabular}

Levels of significance: ${ }^{*} \mathrm{p}<0.05$;

\subsection{Regression Results}

Table 4 represents the estimates of linear regression model. The results reveal that energy consumption and GDP growth have positive significant impact on emissions of $\mathrm{CO}_{2}$. The effect of financial development is also positive but insignificant. Interestingly, the impact of private investment on emissions of $\mathrm{CO}_{2}$ is negative meaning that, with more private investment, environmental degradation got reduces in case of Pakistan.

The results further show that 1\% rise in energy consumption and GDP degrades environment by $1.88 \%$ and $0.033 \%$ respectively. These empirical results are like the results of Munir and Khan (2010), Hitam et al. (2012), Siddique et al (2016), Pata (2017), Pan et al. (2019). Similarly, 1\% improvement in financial development leads to contaminate environment by $0.012 \%$. The result is supported by Sadosky (2001), Shahban and Lean (2012), Islam et al. (2013) and Tang and Tan (2014). The researchers argued that due to financial development, demand of consumers' goods i.e. home appliances like air conditioner, refregirator etc and producers' goods; investment, increase in vehicle, machinery etc. increases thus contributing to $\mathrm{CO}_{2}$ emissions. In addition, $1 \%$ increase in private investment brings $0.005 \%$ decrease in $\mathrm{CO}_{2}$ emissions. Likewise, Talukdar and Meisner (2001) also confirmed negative cointegration between private investment and emissions of $\mathrm{CO}_{2}$ in developing countries whereas, Hassan (2018) found positive association of private investment with $\mathrm{CO}_{2}$ emissions in Malaysia. 
Table 4 Regression Results

\begin{tabular}{|l|c|}
\hline \multicolumn{2}{|c|}{ DV is $\mathbf{C O}_{2}$} \\
\hline Variables & Coefficients \\
\hline C & -11.906 \\
& $(0.000)$ \\
\hline PRI & -0.005 \\
& $(0.356)$ \\
\hline EG & $0.033^{*}$ \\
& $(0.011)$ \\
\hline FD & 0.012 \\
& $(0.625)$ \\
\hline KT & $1.879^{*}$ \\
& $(0.000)$ \\
\hline R & 0.965 \\
\hline DV Dependent variable & \\
\hline
\end{tabular}

* significant at 5\% significant level

\section{Concluding Remarks}

Private investment has an important role in the growth process of an economy but its impact on environmental degradation is ignored by researchers. The main purpose of this study was to analyse the relationship of private investment with environmental degradation in Pakistan.

The estimates of linear regression model confirmed a negative impact of private investment on $\mathrm{CO}_{2}$ emissions in Pakistan. It means that private investment is in favour of environment in case of Pakistan however, the impact of energy consumption, Financial development and GDP growth on emissions of $\mathrm{CO}_{2}$ is positive meaning that all the variables are degrading environment in Pakistan.

On the basis of the results, it is recommended that in Pakistan, policies regarding GDP growth and financial development should be revised and more attention should be given to private investment to reduce emissions of $\mathrm{CO}_{2}$ in the country.

\section{References}

Akbostanci, E., Turut-AsIk, S., \& Ipek, T. G. (2009). The relationship between income and environment in Turkey: is there an environmental Kuznets curve. Energy Policy 37(3): pp. 861-867.

Albiman, M. M., Suleiman, N. N., \& Baka, H. O. (2015). The relationship between energy consumption, $\mathrm{CO} 2$ emissions and economic growth in Tanzania. International Journal of Energy Sector Management, 9(3): pp. 361-375.

Ali, H. S., Law, H. S., \& Zannah, T. I. (2016). Dynamic impact of urbanization, economic growth, energy consumption, and trade openness on $\mathrm{CO}_{2}$ emissions in Nigeria.Environmental Sciences and Pollution Research, 23(11):

Al-mulali, U., Fereidouni, H. G., Lee, J. Y.M., \& Sab, C. N.B. (2013). Exploring the relationship 


\section{Review of Economics and Development Studies, Vol. 7 (1) 2021, 13-24}

between urbanization, energy consumption, and $\mathrm{CO}_{2}$ emission in MENA countries, Renewable and Sustainable Energy Reviews, Elsevier, 23 : pp. 107-112

Ang, J. B. (2007). CO2 emissions, energy consumption, and output in France. Journal of Energy Policy, 35: pp. 4772-4778.

Anwar, M. S., \& Sampath, R. K. (1999). Investment and Economic growth. Department of Agriculture and Resource economics Colorado State University. Forgo, ND.

Azam, M., Khan, A. Q., Abdullah, B. H., \& Qureshi, M. E.(2016). The impact of CO2 emissions on economic growth: evidence from selected higher $\mathrm{CO} 2$ emissions economies, 23(7): pp. 637689.

Azam, M., Khan, A.Q., \& Ozturk, I. (2019). The effects of energy on investment, human health, environment and economic growth: empirical evidence from China. Environmental Science and Pollution Research, 26: pp.10816-10825.

Borhan, H., Ahmed, E. M., \& Hitam, M. (2012). The impact of $\mathrm{CO} 2$ on economic growth in ASEAN 8. Procedia-Social and Behavioral Sciences, 35: pp. 389-397.

Cederborg, J., \& Snobohm, S. (2016). Is there a relationship between economic growth and carbon dioxide emissions?. Mentor: StigBlomskogSodertorns University | Institution of Social Sciences Bachelor thesis.

Dhakal, S. (2009). Urban energy use and carbon emissions from cities in China and policy implications. Energy Policy, 37: pp. 4208-4219.

Dickey, D., \& Fuller, W. (1979). Distribution of the estimators for autoregressive time series with a unit root. J Am Stat Assoc 74: pp. 427-431

Fu, F., Ma, L., Li, Z., \& Polenske, K. R. (2014). The implications of China's investment-driven economy on its energy consumption and carbon emissions. Energy Conversion and Management 85: pp. 573-580

Fodha, M., \& Zaghdoud, O. (2010). Economic growth and pollutant emissions in Tunisia: an empirical analysis of the environmental Kuznets curve. Energy Policy, 38: pp.1150- 1156.

Government of Pakistan (GOP), Economic Survey 2016-17, Economic advisors wing, Ministry of Finance, Islamabad.

Gokmenoglu, K. K., \& Sadeghieh, M. (2019). Financial Development, CO2 Emissions, Fossil Fuel Consumption and Economic Growth: The Case of Turkey. Strategic Planning for Energy and the Environment, 38(4): pp.7-28.

Grossman, G., \& Krueger, A. (1991). Environmental impacts of a North American free trade agreement, Working Paper No. 3194, National Bureau of Economics Research.

Grossman, G. M., \& Krueger, A. B. (1995). Economic Growth and the Environment. The Quarterly Journal of Economics, 110(2): pp. 353-377.

Halicioglu, F. (2009). An econometric study of CO2 emissions, energy consumption, income and foreign trade in Turkey. Energy Policy 37: pp. 1156-1164.

Hammami, S., \& Saidi, K. (2015). The impact of energy consumption and $\mathrm{CO} 2$ emissions on economic growth: Fresh evidence from dynamic simultaneous-equations models. Sustainable Cities and Society, 14: pp. 178-186.

Hassan, S. (2018). Dynamic Impact of Energy Consumption, Private Investment and Financial Development on Environmental Pollutions: Evidence from Malaysia. International Journal of Energy Economics and Policy, 8(4): pp. 63-69.

Hitam, M., Ahmed, E. M., \& Borhan, H. (2012). The impact of $\mathrm{CO} 2$ on economic growth in ASEAN 8. Procedia-Social and Behavioral Sciences, 35: pp.389-397.

Hye, Q. M. A., Shahbaz, M., Tiwari, A. K., \& Leitao, N. C. (2013). Economic growth, energy consumption, financial development, international trade and $\mathrm{CO}_{2}$ emissions in 


\section{Review of Economics and Development Studies, Vol. 7 (1) 2021, 13-24}

Indonesia. Renewable and Sustainable Energy Reviews, 25: pp. 109-121.

Islam, F., Shahbaz, M., Ahmed, A. U., \& Alam, M. M. (2013). Financial development and energy consumption nexus in Malaysia: a multivariate time series analysis. Economic Modelling, 30: pp. 435-441.

Jalil, A., \& Feridun, M. (2011). The impact of growth, energy and financial development on the environment in China: A cointegration analysis. Energy Economics, 33(2): pp. 284-291.

Jalil, A., \& Mahmud, S. (2009). Environment Kuznets curve for CO2 emissions: a co-integration analysis for China. Journal of Energy Policy, 37: pp. 5167-5172.

Jamel, L., \& Derbali, A. (2016). Do energy consumption and economic growth lead to environmental degradation? Evidence from Asian economies. Cogent Economics \& Finance, 4(1): 1170653 .

Jayanthakumaran, K., Verma, R., \& Liu, Y. (2012). CO2 emissions, energy consumption, trade and income: a comparative analysis of China and India. Energy Policy 42: pp. 450-46o

Johansen, S. (1991). Estimation and hypothesis testing of cointegration vectors in Gaussian vector autoregressive models. Econometrica 59: pp. 1551-1580

Johansen, S. (1995). Likelihood-based inference in cointegrated vector autoregressive models. Oxford University Press, New York.

Kivyiro, P., \& Arminen, H. (2014). Carbon dioxide emissions, energy consumption, economic growth, and foreign direct investment: Causality analysis for Sub-Saharan Africa. Energy, 74: pp. 595-606.

Kizilkaya, O. (2017). The impact of economic growth and foreign direct investment on $\mathrm{CO}_{2}$ emissions: the case of Turkey. Turkish Economic Review, 4(1): pp. 106-118.

Majeed, M. T., \& Khan, S. (2008). The Determinants of Private Investment and the Relationship between Public and Private Investment in Pakistan', Journal of Business and Economics, 1(1): pp. 41-48.

Muhammad , M. A. \& Shaheen, S. (2016). An Analysis Of Determinants Of Private Investment In Pakistan. International Interdisciplinary Journal of Scholarly Research (IIJSR). 2(2) : pp. 2412-303.

Munir, S., \& Khan, A. (2014). Impact of Fossil Fuel Energy Consumption on CO2 Emissions: Evidence from Pakistan (1980-2010). Pakistan Development Review, 53(4): pp. 327.

Pata, U. (2017). The effect of urbanization and industrialization on carbon emissions in Turkey: evidence from ARDL bounds testing procedure. Environmental Sciences and Pollution Research, 25(8): pp.7740-7747.

Phillips, P. C. B., \& Perron, P. (1988). Testing for a unit root in time series regression. Biometrika, 75(2): pp. 335-346

Poumanyvong, P., \& Kaneko, S. (2010). Does urbanization lead to less energy use and lower CO2 emissions? A cross-country analysis. Ecological Economics, 70: pp. 434-444.

Saboori, B., Suleiman, J., \& Mohd, S. (2012). Economic growth and CO2 emissions in Malaysia: a cointegration analysis of the environmental Kuznets curve, Energy Policy, 51, pp. 184-191.

Sadorsky, P. (2011). The impact of financial development on energy consumption in emerging economies, Energy Policy, 38(5): pp. 2528-2535.

Sehrawat, M., Giri, A. K., \& Mohapatra, G. (2015). The impact of financial development, economic growth and energy consumption on environmental degradation: Evidence from India. Management of Environmental Quality: An International Journal, 26(5): pp. 666-682.

Selden, T.M., \& Song, D. (1994). Environmental quality and development: is there a Kuznets curve for air pollution emission. Journal of Environmental Economics and Management, 27(2) : pp. 147-162. 
Shahbaz, M., \& Lean, H. H. (2012). The dynamics of electricity consumption and economic growth: A revisit study of their causality in Pakistan. Energy, 39(1): pp. 146-153.

Siddique, H. M. A., Majeed, M. T., \& Ahmad, H. K. (2016). The Impact of Urbanization and Energy Consumption on CO2 Emissions in South Asia. South Asian Studies (1026-678X), 31(2).

Sinha, A., \& Bhatt, M. Y. (2017). Environmental Kuznets Curve for CO2 and NOx emissions: A Case Study of India. European Journal of Sustainable Development, 6(1): pp. 267-276.

Smyth, R., \& Lean, H. H. (2010). CO2 emissions, electricity consumption and output in ASEAN. Applied Energy, 87, 1858-1864.

Song, T., Zheng, T., \& Tong, L. (2008). An empirical test of the environmental Kuznets curve in China: a panel co integration approach. China Economic Review, 19: pp. 381-392.

Tadele, E. A. (2014). An Investigation of Macroeconomic Determinants of Domestic Private Investment Evidence from East Africa. International Institute of Social Studies. The Hague, The Netherlands.

Talukdar, D., \& Meisner, C. M. (2001). Does the private sector help or hurt the environment Evidence from carbon dioxide pollution in developing countries, World Development, 29(5): pp. 827-840.

Tamazian, A., \& Rao, B. B. (2010). Do economic, financial and institutional developments matter for environmental degradation? Evidence from transitional economies, Energy Economics, 32(1): pp. 137-145.

Tamazian, A., Chousa, J.P., \& Vadlamannati, C. (2009). Does higher economic and financial development lead to environmental degradation: evidence from the BRIC countries, Energy Policy, 37(1): pp. 246-253.

Tang, C. F., \& Tan, B. W. (2014). The linkages among energy consumption, economic growth, relative price, foreign direct investment and financial development in Malaysia. Quality \& Quantity, 48(2): pp. 781-797.

Thao, N. T. N., \& Chon, V. L. (2015). Nonrenewable, renewable energy consumption and economic performance in OECD countries: A stochastic distance function approach.

Wolde, E. T. (2015). Economic Growth and Environmental Degradation in Ethiopia: An Environmental Kuznets Curve Analysis Approach. Journal of Economics and International Finance, 7(4) : pp. $72-79$.

York, R. (2007). Demographic trends and energy consumption in European Union Nations, 19602025. Social Science Research, 36(3): pp. 855-872.

Yousaf, et al. (2016). An analysis of foreign aid and environmental degradation in Pakistan using the ARDL bounds testing technique (1972-2013). Environmental Economics, 7(1).

Zhang, Y. J. (2011). The impact of financial development on carbon emissions: an empirical analysis in China, Energy Policy, 39(4): pp. 2197-2203. 